\title{
Modeling Urban Growth and Land Use Transition Using SLEUTH Model: The Case of Dilla City, Ethiopia
}

\author{
Yanit Mekonnen ( $\nabla$ tinayeth@gmail.com ) \\ Dilla University https://orcid.org/0000-0002-8341-4166 \\ Abel Hailu \\ Dilla University
}

\section{Research article}

Keywords: Land Use transition, Urban growth, GIS, SLEUTH Model

Posted Date: December 22nd, 2020

DOI: https://doi.org/10.21203/rs.3.rs-129793/v1

License: (c) (i) This work is licensed under a Creative Commons Attribution 4.0 International License.

Read Full License 


\title{
Title: Modeling urban growth and land use transition using SLEUTH model: the case of Dilla City, Ethiopia
}

Authors' information: Yanit Mekonnen ${ }^{1}$ and Abel Hailu ${ }^{2}$

${ }^{1,2}$ Dilla University, SNNP, Ethiopia

tinayeth@gmail.com

\begin{abstract}
Urban growth / urban sprawl are the extension of a residential region into the surrounding area. The negative face of urban development is urban sprawl, criticizing the cause of environmental deterioration, growing inequality and diminishing the viability of aesthetic and urban areas. An effective and efficient planning of urban development and changes in land use and its effects on the environment needs, among other important details, details on development trends and patterns. Over the years, several models of urban growth have been developed and used to predict trends of growth. SLEUTH models are used to simulate and predict urban growth and land use transition for 2020-2050 in the City of Dilla (Ethiopia) in the analysis of Geographic Information System (GIS). The word SLEUTH was derived from the model's input image specifica- tions: slope, land cover, exclusion, urban, transport, and Hill shade. Input data preparation used a cumulative time series dataset of 30 years, i.e. 1989, 1999, 2009 and 2019, such as historical topographical maps and satellite imagery. The SLEUTH model uses the parameters of the best fit growth rule by narrowing coefficients in the calibration mode and passing them down to forecast potential urban growth trends, creating different probability maps and LULC maps. The models generated future urban growth pattern predicted in the 31 years' from 2019 , there will be nearly $41.14 \%$ urban rise in $2020,52.95 \%$ in $2030,59.91 \%$ in 2040 and $64.30 \%$ in 2050 . In general, the extension of the urban growth trend introduces new spreading centers that are indicative of urban growth.
\end{abstract}

Keywords: Land Use transition, Urban growth, GIS, SLEUTH Model

\section{INTRODUCTION}

The effects on the environment and the extent of urban problems have increased and strong imbalances have been created between the city and its surroundings. The need to evaluate and monitor urban planning and management processes and practices is the experience of recent years in terms of urban growth complexity. Since 1990's, several research studies have been the topic of prediction and modeling of urban de- velopment [2]. Urban growth is a relevant field for the study and evaluation of a city's 
sustainable development. Therefore, many methods and models have been built around this problem and written. There are various ways to classify these models and different classifications have been suggested by several authors in their work [14]. SLEUTH is among the many models the most popular model used for modeling and forecasting city expansion.

SLEUTH model was developed by Clark, it is an open-source software that is written in programming language $C$ and runs on UNIX or LINUX [4] and [7]. In the first place, this model is aimed at stimulating urban growth to explore the model and impact of urban enlargement in the city [1] and [9]. The acceptance of SLEUTH and the number of its applications worldwide is due primarily to its open access, source code accessible, urban modeling capability [5], [6], and [10] and its relative facility for calculation and execution. The aims of this study were to compute land use transition in Dilla city from 1989 to 2019; and to forecast urban growth evolution and land use transition in study area from 2020 to 2050 .

\section{DATA AND MATERIELS}

\subsection{Study area}

As shown in Figure 1, the study town of Dilla is situated on the eastern edge of the Rift Valley in Ethiopia, $365 \mathrm{~km}$ from Addis Ababa, the capital, and $96 \mathrm{~km}$ from Ha- wassa, the seat of the SNNP Regional State. It has a long history of being a political administration base for different regimes and currently serves as the Gedeo zone administration capital. It is situated from Addis Ababa to Moyale, at the middle or midpoint. This possession had yielded and improved an opportunity to become a market center only distributor for various cities, villages and rural areas in the surrounding region. Dilla town is located at the northern tip of the political administration map of the Gedeo zone and is bordered by the northern portion of the Sidama zone, the western regional state of Oromiya, the southern Ciicu river and peasant association, and the eastern Gola peasant association. Actually, due to the merger of them through the expansion of both cities, Ciicu town [a small urbanized neighborhood at the immediate border next to the Ciicu River and the center of Dilla zuria woreda] has begun to become part of Dilla town as a one-sub-city under Dilla administration. It is situated 1600 meters above sea level and is humid all year round (Wikipedia).

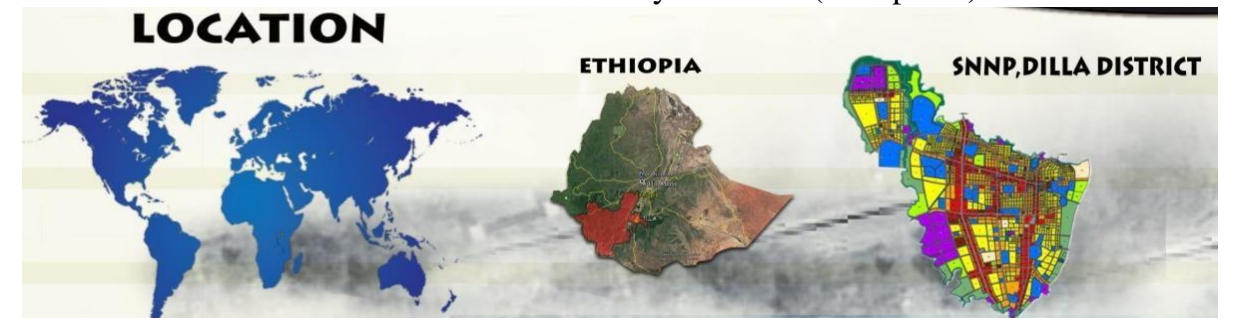

Fig. 1. Analysis area 


\subsection{Introduction to SLEUTH model}

The SLEUTH model's name refers to the data it required: slope, land use, excluded area, urban area, transport network and Hillshade [12]. The two main features of the model are: the deltatron (LDM) land cover model and the urban growth model (UGM). The model is based on five coefficients to control the dynamics of the con-sidered urban development: diffusion, breed, spread, slope and road gravity, in order to generate four types of growth rules: spontaneous growth, new spreading center growth, edge growth, and growth of road gravity [13].

The calibration of the model is an important step in the SLEUTH model-based urban expansion prediction process. This process consists in computing a set of growth coefficient values that can reliably replicate the historic urban growth happening in the research field based on the input model data [7] and [6]. SLEUTH is typically adjusted in 3 steps allowing to the user's requirements: coarse, fine and final scale. The input data are tried at a lower resolution in the first step to cover the entire space. To calculate and classify the effects, larger increments in the parameters are also used. In subsequent steps, thinner increments and higher resolutions are then used [8].

\section{METHODS}

\subsection{Input data collection and preparation}

The input data required to compile the model, including slope, land cover, excluded area, road network and sun exposure, were obtained from the supervised satellite image classification. The digitization of objects on cartographic maps has provided additional data, in particular data relating to the development plan of the urban. Therefore, we used a time series of ten $30 \mathrm{~m}$ resolution LANDSAT $7 \& 8$ satellite images acquired from 1989 to 2019 in this analysis (Figure 2). We've also used vector data to approve urban building projects by 2019. As well as vector data relevant to Dilla's Master Plan for Urban Development, this will guide the urban growth over the next 20 years. All satellite images used in this work have been downloaded from the USGS earth explorer.

From the supervised satellite image classification, the input data is required to compile the model, including slope, land cover, excluded area, road network and sun exposure. Additional details, including the urban's development plan, have been generated by the digitization of items on cartographic maps. In this study, we used a $30 \mathrm{~m}$ DEM, LANDSAT $7 \& 8$ time series of satellite pictures that were obtained 1989 to 2019 (Figure 2). We also used vector data for the approval of projects for urban construction till 2019. The USGS earth explorer is source of downloaded satellite images used in this work. 
Table 1. Data requirements for the model

\begin{tabular}{|l|c|c|}
\hline Layer & $\begin{array}{c}\text { Input Data Types, } \\
\text { Organized though }\end{array}$ & $\begin{array}{c}\text { Arrangement \& Input Data } \\
\text { Years' }\end{array}$ \\
\hline Slope & Derived from DEM & Raster (in \%) \\
\hline Land use & $\begin{array}{c}\text { Supervised classified of } \\
\text { satellite image }\end{array}$ & Raster, 1989 \&2019 \\
\hline Excluded area & Rasterized from vector & Rasterized from vector \\
\hline Urban & $\begin{array}{c}\text { Supervised classified of } \\
\text { satellite image }\end{array}$ & Raster, 1989, 1999, 2009, 2019 \\
\hline Transport & $\begin{array}{c}\text { digitized from master } \\
\text { plan using ArcGis 10.3 }\end{array}$ & $\begin{array}{c}\text { Rasterized from vector, 1989, } \\
1999,2009,2019\end{array}$ \\
\hline Network & Derived from DEM & Raster \\
\hline Hillshade & \multicolumn{2}{|c}{} \\
\hline
\end{tabular}

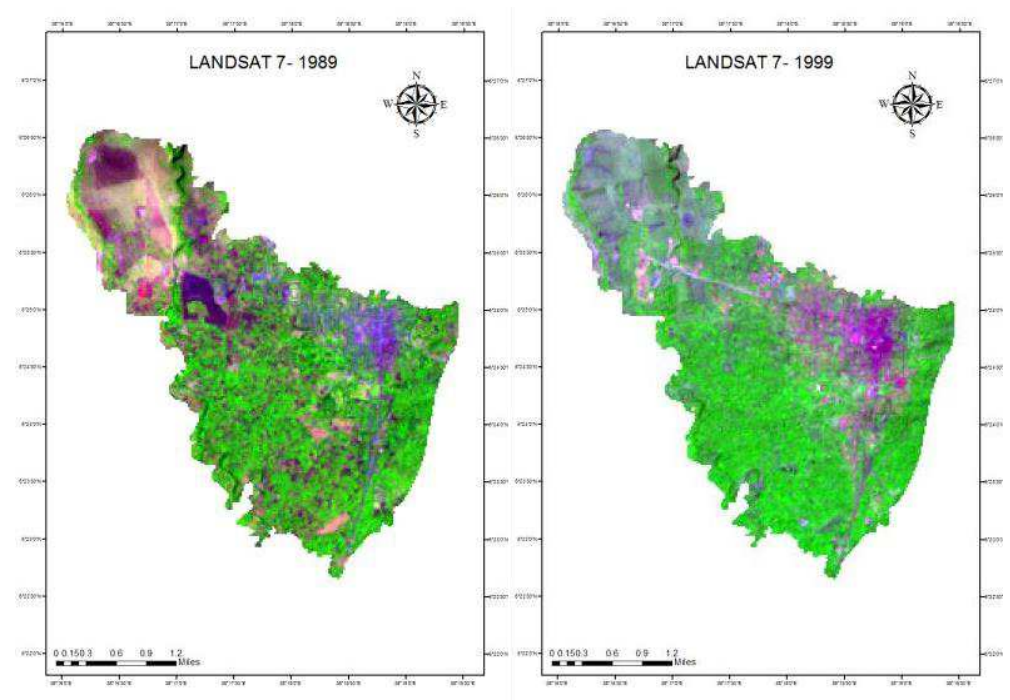




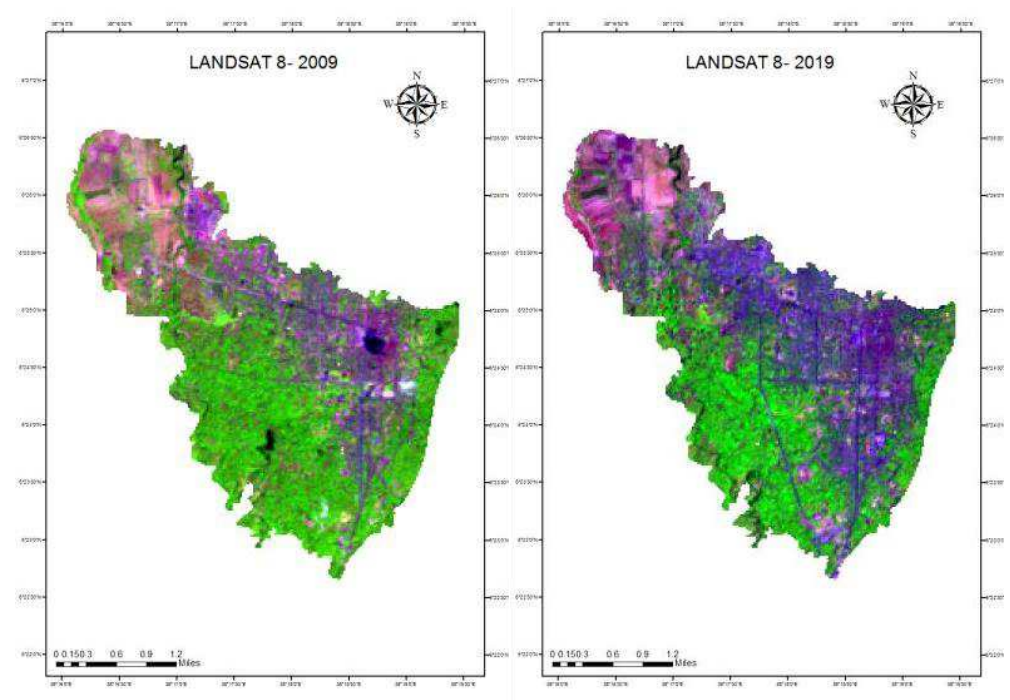

Fig. 2. Landsat satellite data of different years

Input data were arranged and evaluated using ArcGIS 10.3, Cygwin and SLEUTH 3.0.0. to achieve the prediction of dynamic urban growth in Dilla city. A supervised classification of these images has made it possible to obtain different classes representing: urban, agricultural, water, forestry and vegetation, as shown in Table 1 and Figure 3.

Table 2. Distribution of study area in $\mathrm{km} 2$ for individual year

\begin{tabular}{|l|l|l|l|l|l|l|l|l|}
\hline \multirow{2}{*}{ Class name } & \multicolumn{9}{|c|}{ Area, km2 } & \% \\
\cline { 2 - 10 } & 1989 & $\%$ & 1999 & $\%$ & 2009 & $\%$ & 2019 & 38.8 \\
\hline Urban & 42.8 & 19.9 & 53.7 & 24.9 & 72.9 & 33.8 & 83.7 & 38.9 \\
\hline Agriculture & 29.8 & 13.8 & 34.2 & 15.9 & 32.4 & 15.1 & 59.5 & 27.6 \\
\hline Forest & 87.3 & 40.5 & 88.4 & 41 & 43.2 & 20 & 29.8 & 13.8 \\
\hline Vegetation & 36.5 & 16.9 & 29.1 & 13.5 & 33.3 & 15.5 & 29.1 & 13.5 \\
\hline Water & 19.1 & 8.9 & 10.1 & 4.7 & 33.7 & 15.6 & 13.4 & 6.3 \\
\hline Total & 215.5 & 100 & 215.5 & 100 & 215.5 & 100 & 215.5 & 100 \\
\hline $\begin{array}{l}\text { Overall } \\
\text { Accuracy (\%) }\end{array}$ & 90.0 & 91.43 & & 93.33 & & 90.0 & \\
\hline $\begin{array}{l}\text { Kappa } \\
\text { Coefficient }\end{array}$ & 0.83 & & 0.87 & & 0.90 & & \multirow{2}{*}{0.82} \\
\hline
\end{tabular}



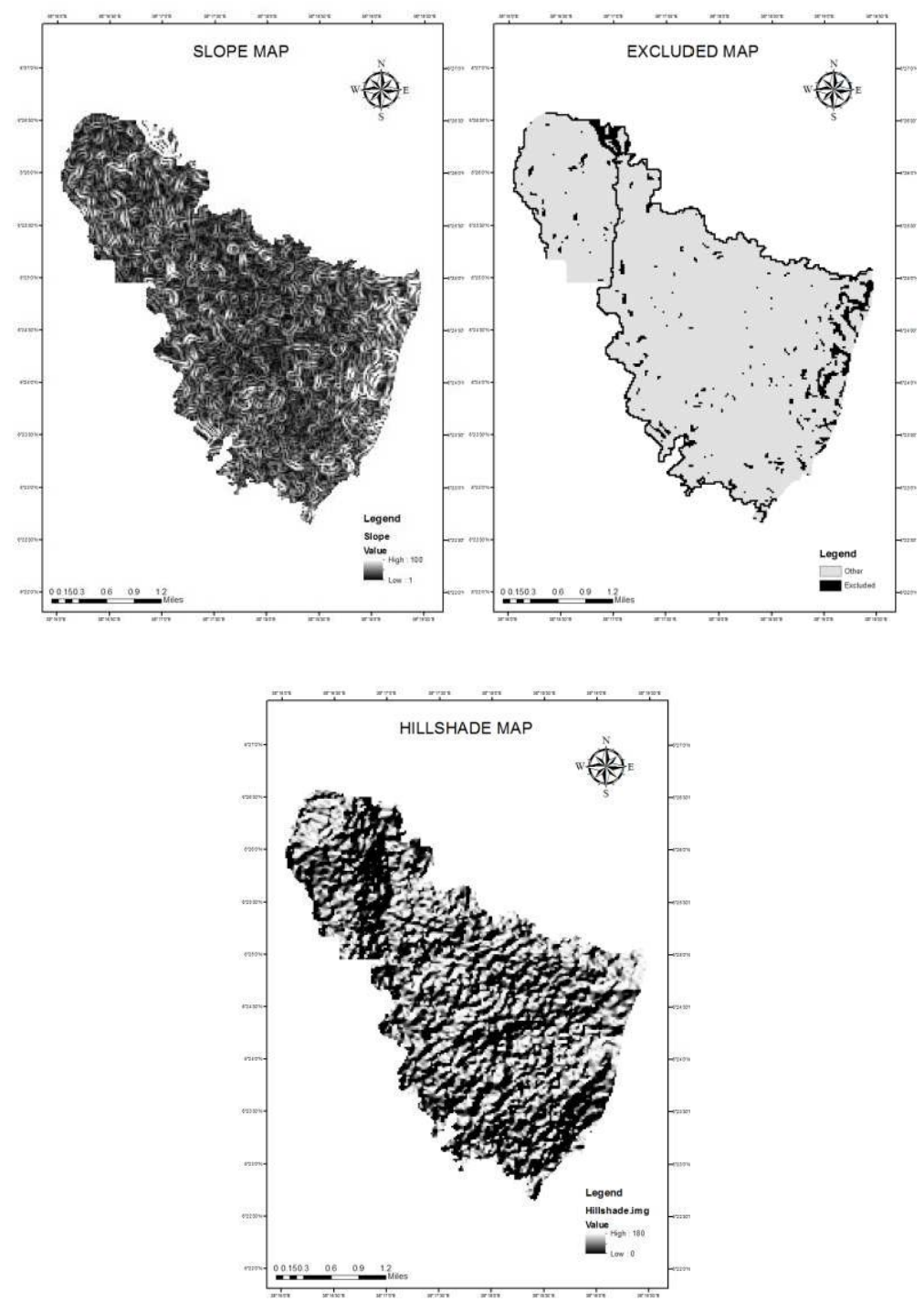

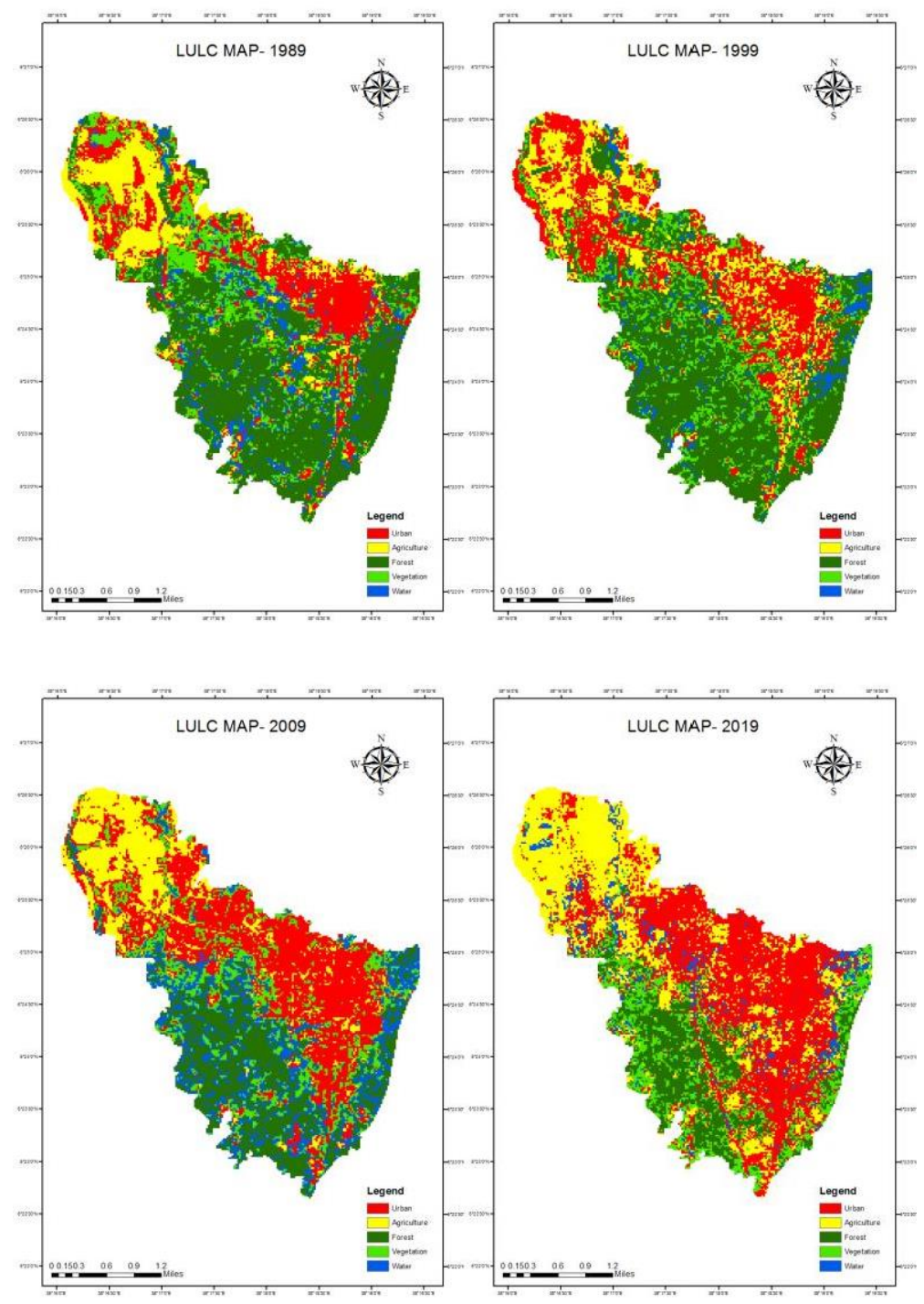

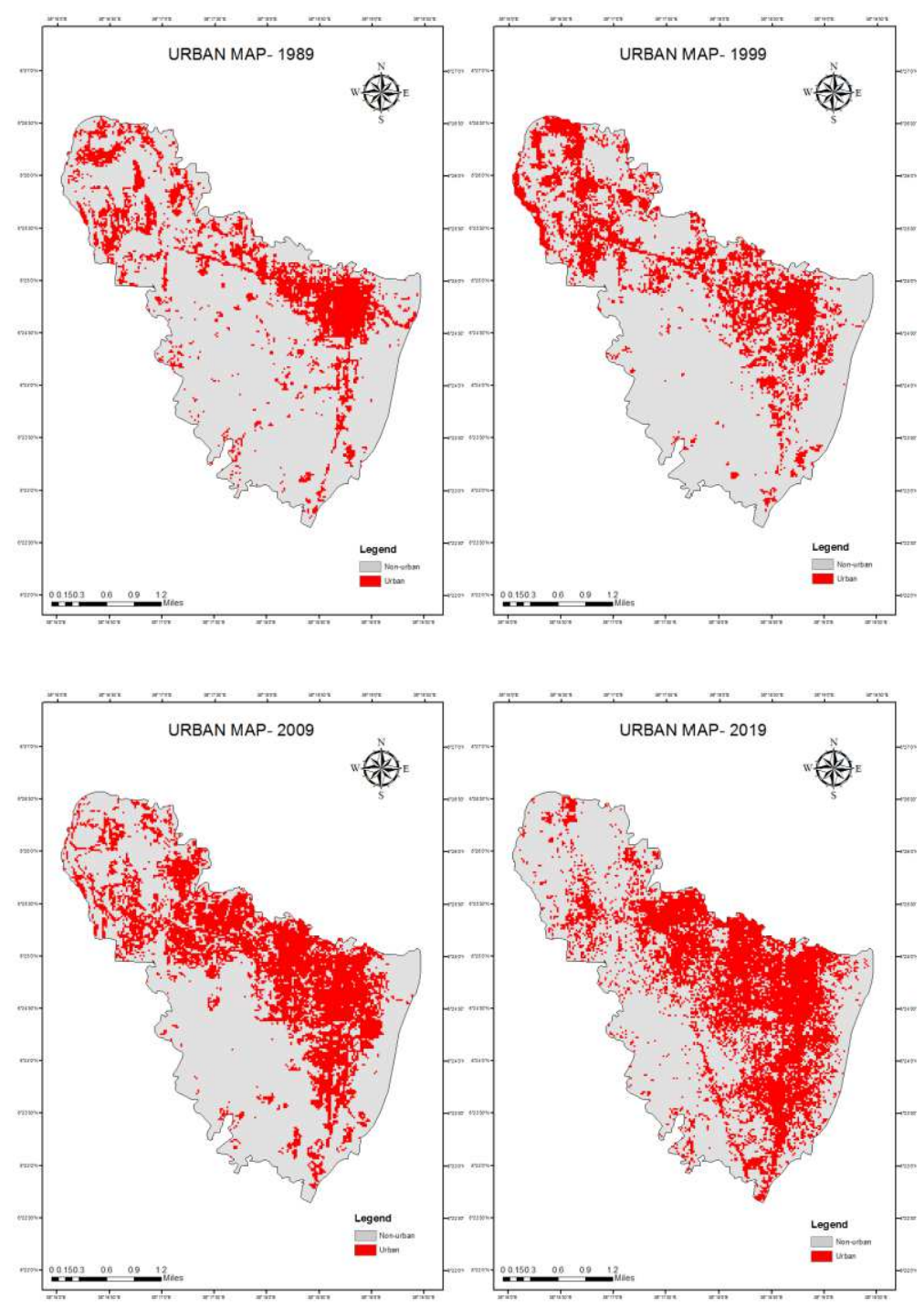

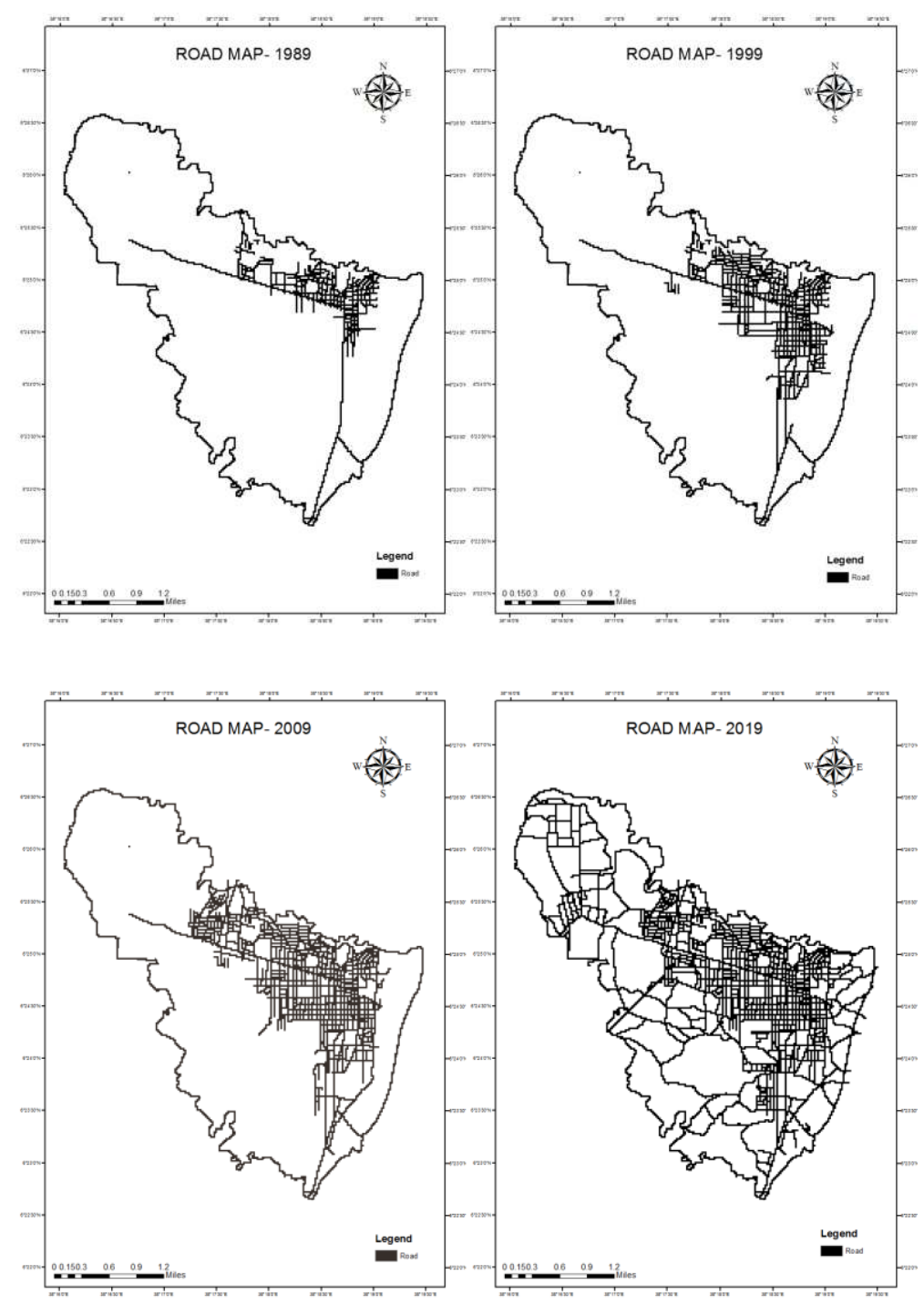

Fig. 3. Input Data set for model calibration

The SLEUTH model, based on the simulation from Monte Carlo, was calibrated with three steps: coarse, fine and final. Therefore, a set of stop-dates for initializing forecasting would be generated with the best parameters resulting from the SLEUTH calibration for the historic period [11][3]. 
The first step was to provide data the original resolution of $30 \mathrm{~m}$, the second step data's was resampled to $1 / 2$ th times the original resolution of $15 \mathrm{~m}$, and the final calibration resampled to $1 / 4$ th times the original resolution of $7.5 \mathrm{~m}$.

\section{RESULTS AND DISCUSSION}

Modeling for urban growth was achieved using the SLEUTH model. The results of modeling are given in terms of various spatial metrics. The first stage of research is to prepare input datasets. Urban growth based on the SLEUTH model has been established when considering different urban driving factors. (Table 3) The SLEUTH parameter was carefully set to avoid over-fitting the model. Different measures have been taken to optimally choose the SLEUTH simulation's best fitting attribute. Urban growth has been projected for 2020, 2030, 2040 and 2050 once the model value is evaluated. In addition, for future years, the device output simulates the LULC map.

Table 3. The finest results of the calibration parameters through the phases

\begin{tabular}{|c|c|c|c|c|c|}
\hline \multirow{2}{*}{ Mode } & \multicolumn{3}{|c|}{ Calibration mode } & \multirow{2}{*}{$\begin{array}{l}\text { Forecast } \\
\text { mode }\end{array}$} & \multirow{2}{*}{$\begin{array}{l}\text { Predict } \\
\text { mode }\end{array}$} \\
\hline & Coarse & Fine & Final & & \\
\hline $\begin{array}{l}\text { Total number } \\
\text { of Pixel dimen- } \\
\text { sion }\end{array}$ & $(1732 \times 2204)$ & $(866 \times 1102)$ & $(433 \times 551)$ & $(433 \times 551)$ & $(433 \times 551)$ \\
\hline \multirow[t]{3}{*}{$\begin{array}{l}\text { Growth } \\
\text { parameter }\end{array}$} & $\begin{array}{l}\mathrm{MC} \\
\text { iterations= } \\
4\end{array}$ & $\begin{array}{l}\mathrm{MC} \\
\text { iterations= } \\
7\end{array}$ & $\begin{array}{l}\text { MC } \\
9^{\text {iterations }=}\end{array}$ & $\begin{array}{l}\text { MC } \\
\text { iterations= } \\
100\end{array}$ & $\begin{array}{l}\text { MC } \\
\text { iterations= } \\
100\end{array}$ \\
\hline & $\begin{array}{c}\text { Lee-Sallee } \\
\text { statistic }=0.33\end{array}$ & $\begin{array}{c}\text { Lee-Sallee } \\
\text { statistic }=0.32\end{array}$ & $\begin{array}{c}\text { Lee-Sallee } \\
\text { statistic }=0.31\end{array}$ & $\begin{array}{r}\text { Lee-Sallee } \\
\text { statistic }=0.3\end{array}$ & $\begin{array}{r}\text { Lee-Sallee } \\
\text { statistic }=0.3\end{array}$ \\
\hline & $\begin{array}{l}\text { Range \& } \\
\text { Step }\end{array}$ & $\begin{array}{l}\text { Range \& } \\
\text { Step }\end{array}$ & $\begin{array}{l}\text { Range \& } \\
\text { Step }\end{array}$ & $\begin{array}{l}\text { Range \& } \\
\text { Step }\end{array}$ & $\begin{array}{cc}\text { Best fit } \\
\text { values }\end{array}$ \\
\hline Dispersion & $\begin{array}{c}0-100 \\
25\end{array}$ & $\begin{array}{c}0-20 \\
5\end{array}$ & $\begin{array}{c}1-5 \\
1\end{array}$ & $\begin{array}{c}1-1 \\
1\end{array}$ & 7 \\
\hline Breed & $\begin{array}{c}0-100 \\
25\end{array}$ & $\begin{array}{c}25-100 \\
10\end{array}$ & $\begin{array}{c}35-85 \\
5\end{array}$ & $\begin{array}{c}45-45 \\
1\end{array}$ & 100 \\
\hline Spread & $\begin{array}{c}0-100 \\
25\end{array}$ & $\begin{array}{c}0-25 \\
5\end{array}$ & $\begin{array}{c}22-28 \\
1\end{array}$ & $\begin{array}{c}28-28 \\
1\end{array}$ & 37 \\
\hline Slope & $\begin{array}{c}0-100 \\
25\end{array}$ & $\begin{array}{c}0-20 \\
5\end{array}$ & $\begin{array}{c}1-5 \\
1\end{array}$ & $\begin{array}{c}1-1 \\
1\end{array}$ & 9 \\
\hline Road gravity & $\begin{array}{c}0-100 \\
25\end{array}$ & $\begin{array}{c}50-100 \\
10\end{array}$ & $\begin{array}{c}50-100 \\
5\end{array}$ & $\begin{array}{c}50-50 \\
1\end{array}$ & 100 \\
\hline
\end{tabular}


The breed coefficient of prediction has a high value of 100 in the prediction coefficient, as shown in Table 4. The high breed parameter demonstrates that significant urban growth in Dilla is new spread from centers. In this analysis, the spread coefficient is 37 , which shows that another significant growth form in this area is organic growth or edge growth. The low slope coefficient, 9, indicates that urban development was not a limiting factor in the topography. The value of the diffusion coefficient of 7 indicates that there is almost no random urbanization of the land, key urbanization near existing urban areas and new urban centers. The value of the road gravity coeffi- cient of 100 suggests that urban development has had a significant effect on road networks and is increasingly influenced by actual road patterns.

Table 4. Distribution of study area in $\mathrm{km} 2$ for individual year

\begin{tabular}{|l|l|l|l|l|l|l|l|l|}
\hline \multirow{2}{*}{ Class name } & \multicolumn{6}{|l|}{ Area, km2 } & \multicolumn{1}{l|}{} \\
\cline { 2 - 9 } & 2020 & $\%$ & 2030 & $\%$ & 2040 & $\%$ & 2050 & $\%$ \\
\hline Urban & 88.66 & 41.14 & 114.11 & 52.95 & 129.11 & 59.91 & 138.56 & 64.30 \\
\hline Agriculture & 56.85 & 26.38 & 42.31 & 19.63 & 33.86 & 15.71 & 27.78 & 12.89 \\
\hline Forest & 29.17 & 13.54 & 24.48 & 11.36 & 19.93 & 9.25 & 17.71 & 8.22 \\
\hline Vegetation & 27.58 & 12.80 & 22.98 & 10.66 & 20.99 & 9.74 & 19.53 & 9.06 \\
\hline Water & 13.24 & 6.14 & 11.62 & 5.39 & 11.61 & 5.39 & 11.92 & 5.53 \\
\hline Total & 215.5 & 100 & 215.5 & 100 & 215.5 & 100 & 215.5 & 100 \\
\hline $\begin{array}{l}\text { Overall } \\
\text { Accuracy (\%) }\end{array}$ & 90.0 & 90.0 & & 91.3 & & 90.0 & \\
\hline $\begin{array}{l}\text { Kappa } \\
\text { Coefficient }\end{array}$ & 0.83 & 0.86 & 0.90 & & & 0.83 \\
\hline
\end{tabular}

(-) represents a decrease

In the classification process, it is shown from Table 4, 5 and 6 and Figure 4 that urban class area increased 23.16 percent for a given period of study from 2020 to 2050 , while agriculture decreased by 13.49 percent, forest decreased by 5.32 percent, vegetation decreased by 3.74 percent and water decreased by 0.61 percent. The difference in water, however, can depend on seasonal changes. Change detection was conducted with the aid of outcomes obtained after classification. 

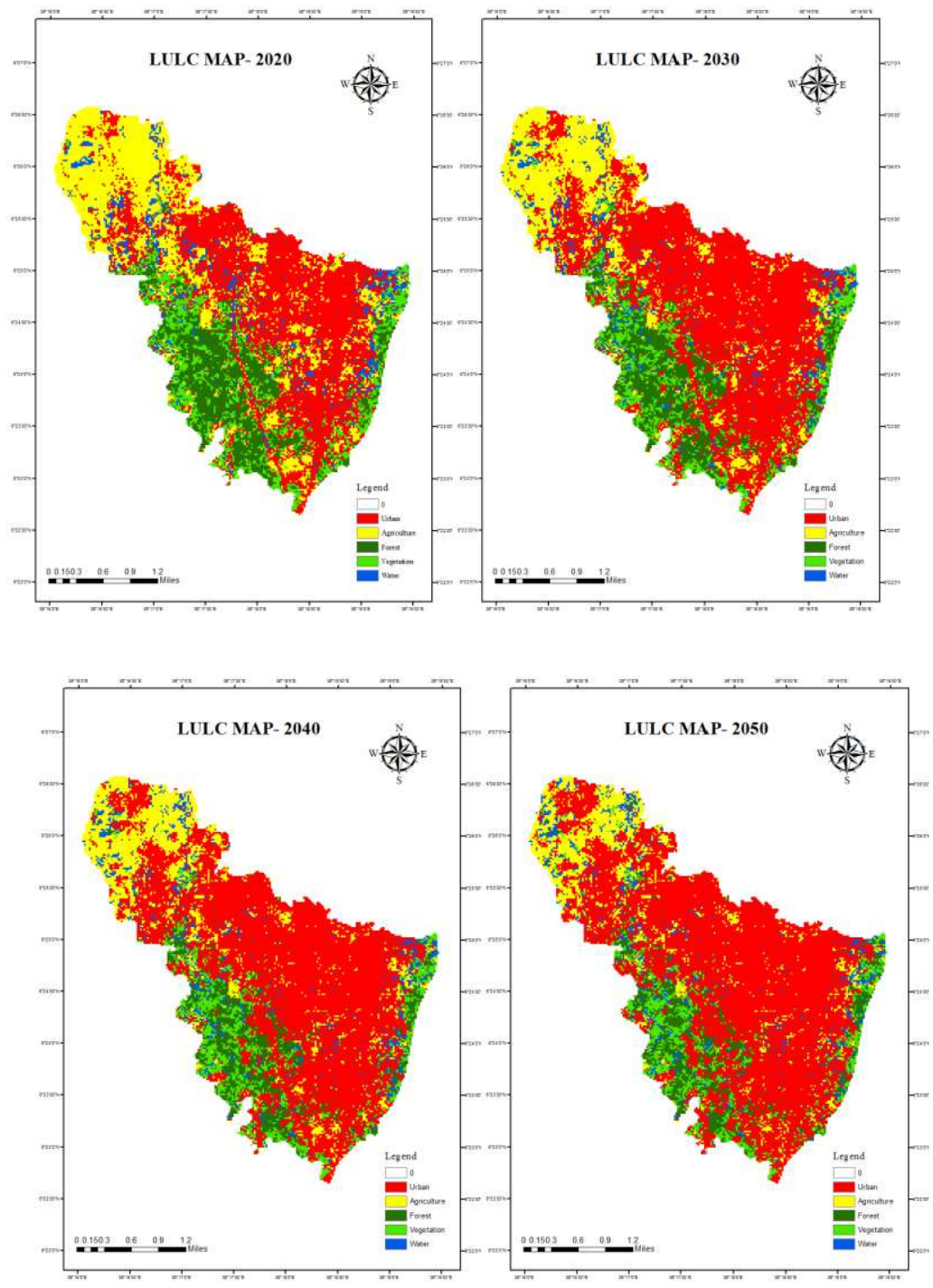

Fig. 4. Land use of the coming years (2020, 2030, 2040 and 2050) 


\section{CONCLUSION AND RECOMMANDATIONS}

The worldwide rise in urban development has started to challenge ecological and environmental conditions. To understand complex urban structures in conjunction with climate, robust methodology and techniques are needed for modeling and simu- lation. The purpose of this study is to incorporate the SLEUTH Model for urban de- velopment and the LULC in the town of Dilla. SLEUTH model role as useful source for enrichment of GIS data layers and value-added layers for planning and GIS use. Such as simulating urban expansion, identification of land use cover, policy reform for zoning or conservation, urban planning and land use planning, techniques for growth management, waste handling, modelling of road networks, energy supply, water supply , waste water disposal, etc. Overall,

1. The study of thirty years of satellite imagery reveals that over the years, urban areas have increased significantly. $42.8 \mathrm{~km} 2$ was registered in 1989 , which rose to $53.7 \mathrm{~km} 2$ in 1999 . The strong influx of migrants has made a significant contribution to the radical rise in urban growth of $72.9 \mathrm{~km} 2$ in 2009 and $83.7 \mathrm{~km} 2$ in 2019 , respectively.

2. The calibration mode is very complex and requires careful adaptation from SLEUTH model analysis. During each combination point, there is a possible com- bination of coefficients in the parameter space which will significantly improve the coefficients of the pattern. The SLEUTH model prediction mode indicates that ap- proximately $4.96 \mathrm{~km} 2$ were transformed into urban areas in 2020, approximately

$30.41 \mathrm{~km} 2$ were transformed into urban areas in 2030, approximately $45.41 \mathrm{~km} 2$ were converted into urban areas in 2040 and approximately $54.86 \mathrm{~km} 2$ were converted into urban areas in 2050.

3. It is also estimated that there will be nearly 41.14 percent urban growth in 2020 in the next 31 years from 2019, 52.95 percent in 2030, 59.91 percent in 2040 and 64.30 percent in 2050.

4. The recurrent model run for potential urbanization trends typically shows new spreading centers, i.e. infilling and outward expansion of established settlements, suggesting a spontaneous growth of a city to develop. Without any protection on resource lands, by 2050, Dilla city is predictable to lose $31.72 \mathrm{~km} 2$ of agricultural land, about $12.09 \mathrm{~km} 2$ of forest land, and approximately $9.57 \mathrm{~km} 2$ of vegetation. 


\section{REFERENCES}

1. Abedini A, Azizi P. Prediction of future urban growth scenarios using SLEUTH model (Case study: Urmia city, Iran). Iran University of Science \& Technology 2016;26:161- 172.

2. Batty M, Xie Y. Possible urban automata. Environment and Planning B: Planning and Design 1997;24:175-192.

3. Bihamta N, Soffianian A, Fakheran S, Gholamalifard M. Using the SLEUTH urban growth model to simulate future urban expansion of the Isfahan metropolitan area, Iran. Journal of the Indian Society of Remote Sensing 2015;43:407-414.

4. Candau JT. Temporal calibration sensitivity of the SLEUTH urban growth model. PhD Thesis. University of California, Santa Barbara, 2002.

5. Chaudhuri G, Clarke K. The SLEUTH land use change model: A review. Environmental Resources Research 2013;1:88-105.

6. Clarke KC. Toward GeoComputational Honesty in Urban Modeling. GeoDynamics 2004:215.

7. Clarke KC, Hoppen S, Gaydos L. A self-modifying cellular automaton model of historical urbanization in the San Francisco Bay area. Environment and Planning B: Planning and Design 1997;24:247-261.

8. Dietzel C, Clarke KC. Replication of spatio-temporal land use patterns at three levels of aggregation by an urban cellular automata. International Conference on Cellular Automata, Springer; 2004, p. 523-532.

9. Jat MK, Choudhary M, Saxena A. Application of geo-spatial techniques and cellular automata for modelling urban growth of a heterogeneous urban fringe. The Egyptian Journal of Remote Sensing and Space Science 2017;20:223-241.

10. Oguz H, Klein AG, Srinivasan R. Using the SLEUTH urban growth model to simulate the impacts of future policy scenarios on urban land use in the Houston-Galveston-Brazoria CMSA. Research Journal of Social Sciences 2007;2:72-82.

11. Rafiee R, Mahiny AS, Khorasani N, Darvishsefat AA, Danekar, Simulating urban growth in Mashad City, Iran through the SLEUTH model (UGM). Cities 2009;26:19-26.

12. Sakieh Y, Amiri BJ, Danekar A, Feghhi J, Dezhkam S. Simulating urban expansion and scenario prediction using a cellular automata urban growth model, SLEUTH, through a case study of Karaj City, Iran. Journal of Housing and the Built Environment 2015;30:591-611.

13. Silva EA, Clarke KC. Calibration of the SLEUTH urban growth model for Lisbon and Porto, Portugal. Computers, Environment and Urban Systems 2002;26:525-552.

14. Timmermans H. Modelling land use and transportation dynamics: methodological issues, state of the art, and applications in developing countries. Urban Planning Group, Eindhoven University of Technology, The Netherlands 2006.

\footnotetext{
* Availability of data and material- Not applicable

* Competing interests- Not applicable

* Funding- Not applicable

* Authors' contributions- Not applicable

* Acknowledgements- Not applicable
} 


\section{Figures}

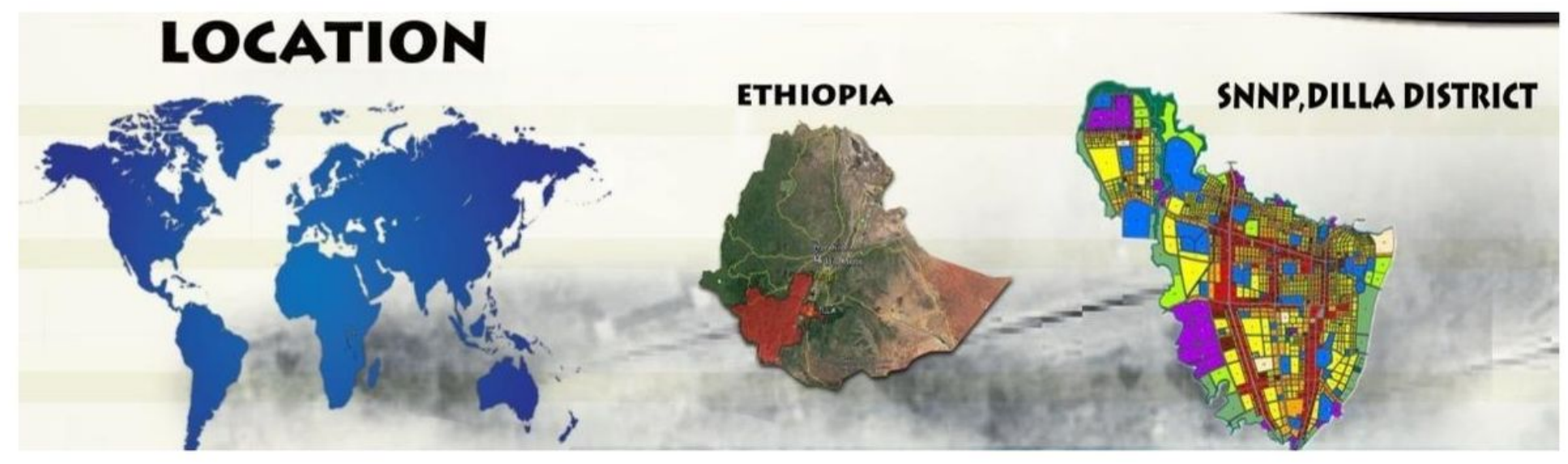

Figure 1

Analysis area. Note: The designations employed and the presentation of the material on this map do not imply the expression of any opinion whatsoever on the part of Research Square concerning the legal status of any country, territory, city or area or of its authorities, or concerning the delimitation of its frontiers or boundaries. This map has been provided by the authors. 

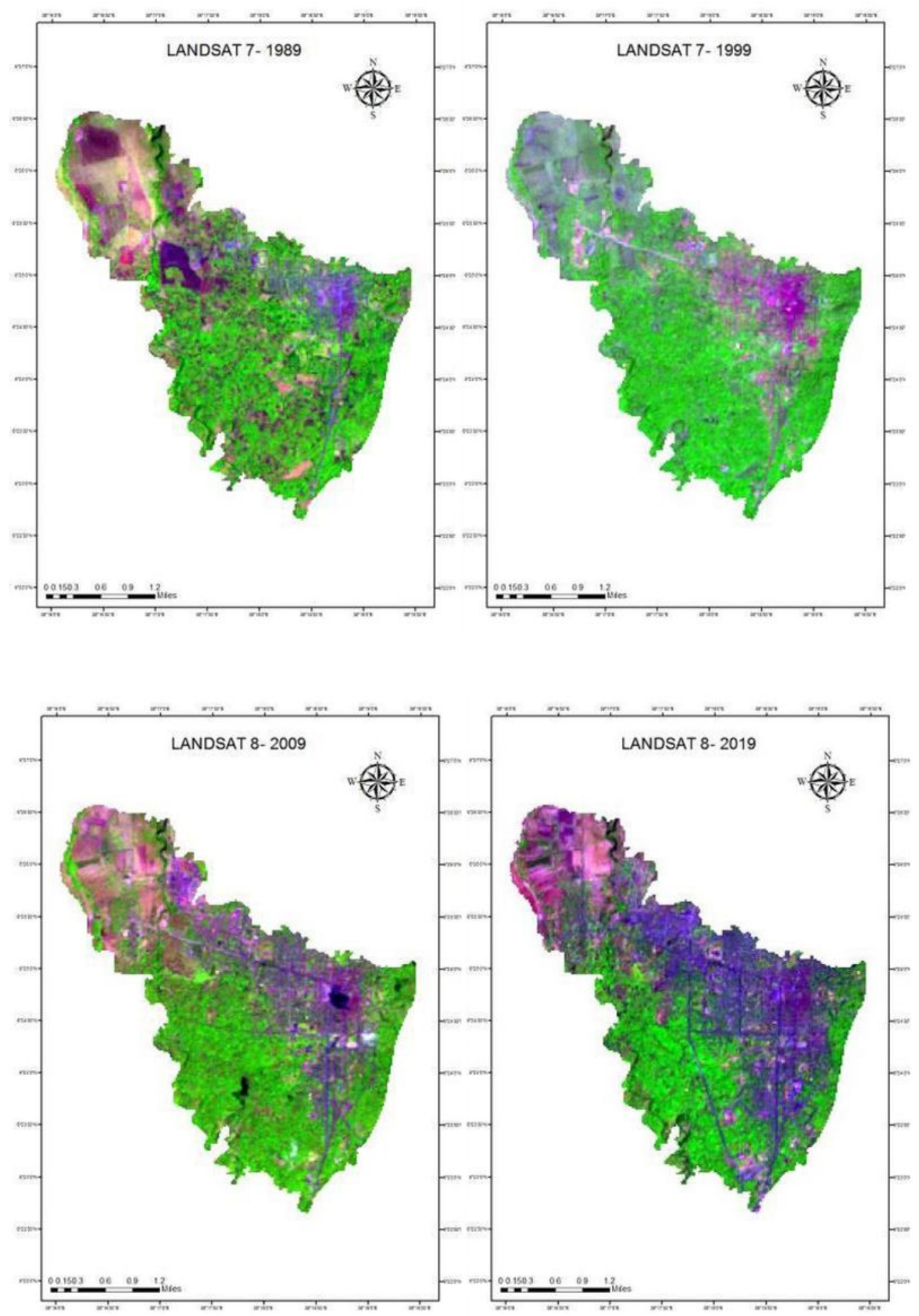

Figure 2

Landsat satellite data of different years. Note: The designations employed and the presentation of the material on this map do not imply the expression of any opinion whatsoever on the part of Research Square concerning the legal status of any country, territory, city or area or of its authorities, or concerning the delimitation of its frontiers or boundaries. This map has been provided by the authors. 

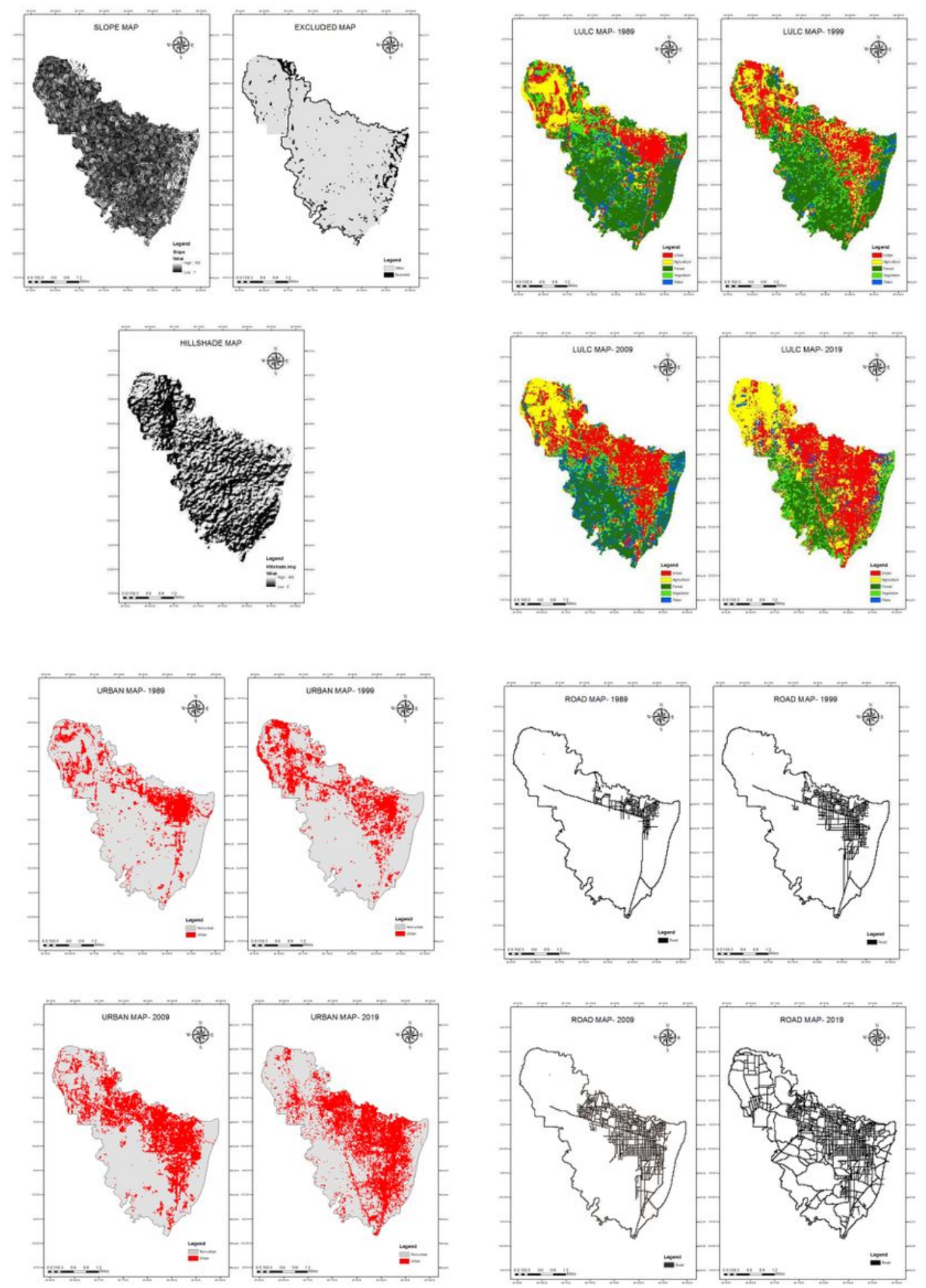

\section{Figure 3}

Input Data set for model calibration. Note: The designations employed and the presentation of the material on this map do not imply the expression of any opinion whatsoever on the part of Research Square concerning the legal status of any country, territory, city or area or of its authorities, or concerning the delimitation of its frontiers or boundaries. This map has been provided by the authors. 

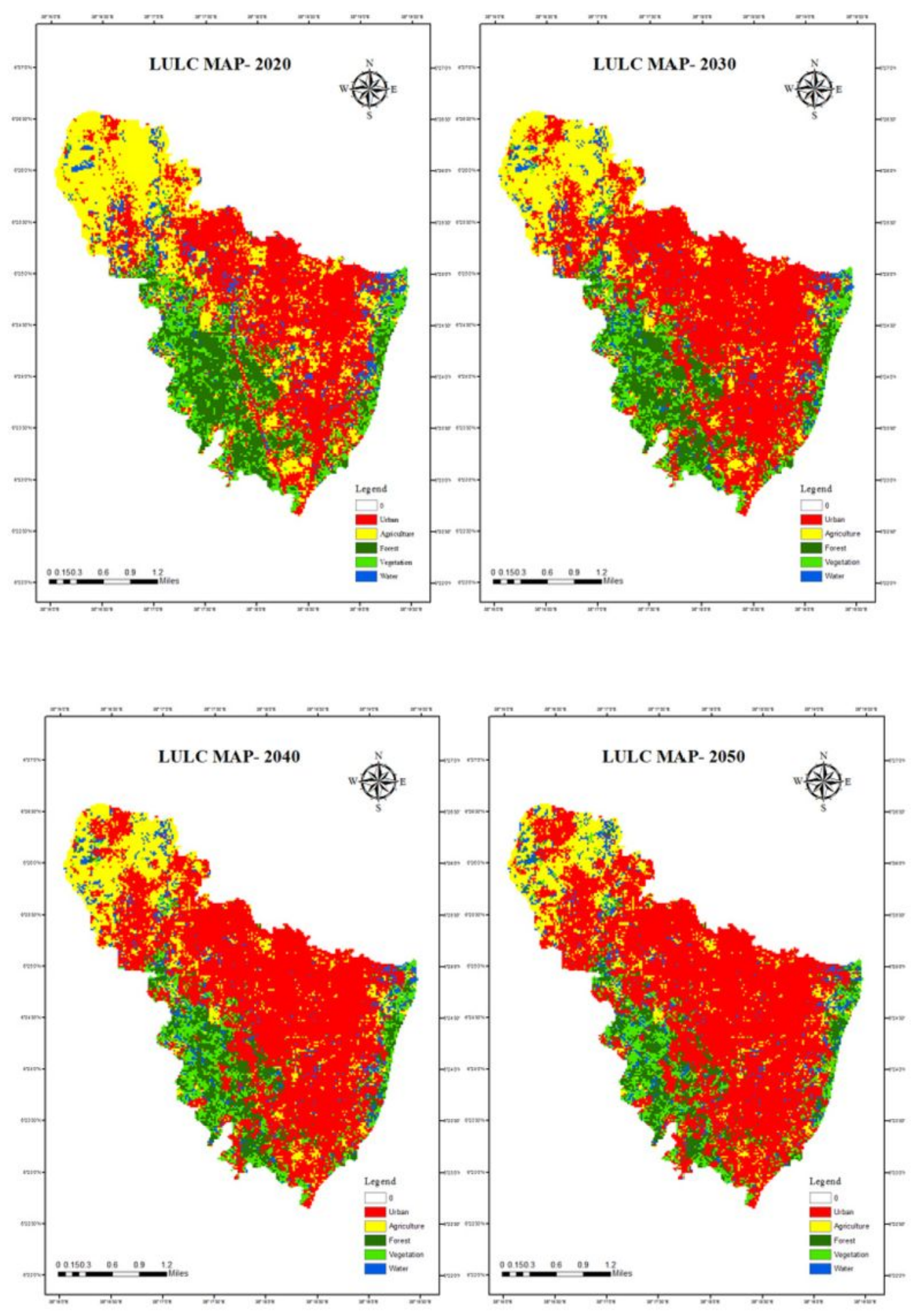

Figure 4

Land use of the coming years $(2020,2030,2040$ and 2050). Note: The designations employed and the presentation of the material on this map do not imply the expression of any opinion whatsoever on the part of Research Square concerning the legal status of any country, territory, city or area or of its authorities, or concerning the delimitation of its frontiers or boundaries. This map has been provided by the authors. 